This item was submitted to Loughborough's Research Repository by the author.

Items in Figshare are protected by copyright, with all rights reserved, unless otherwise indicated.

\title{
Evaluating the institutional sustainability of an urban water utility: a conceptual framework and research directions
}

PLEASE CITE THE PUBLISHED VERSION

http://dx.doi.org/10.1016/j.jup.2013.08.001

PUBLISHER

(C) Elsevier

VERSION

AM (Accepted Manuscript)

LICENCE

CC BY-NC-ND 4.0

\section{REPOSITORY RECORD}

Kayaga, Sam, Josses Mugabi, and William Kingdom. 2019. "Evaluating the Institutional Sustainability of an Urban Water Utility: A Conceptual Framework and Research Directions". figshare.

https://hdl.handle.net/2134/13393. 
This item was submitted to Loughborough's Institutional Repository (https://dspace.lboro.ac.uk/) by the author and is made available under the following Creative Commons Licence conditions.

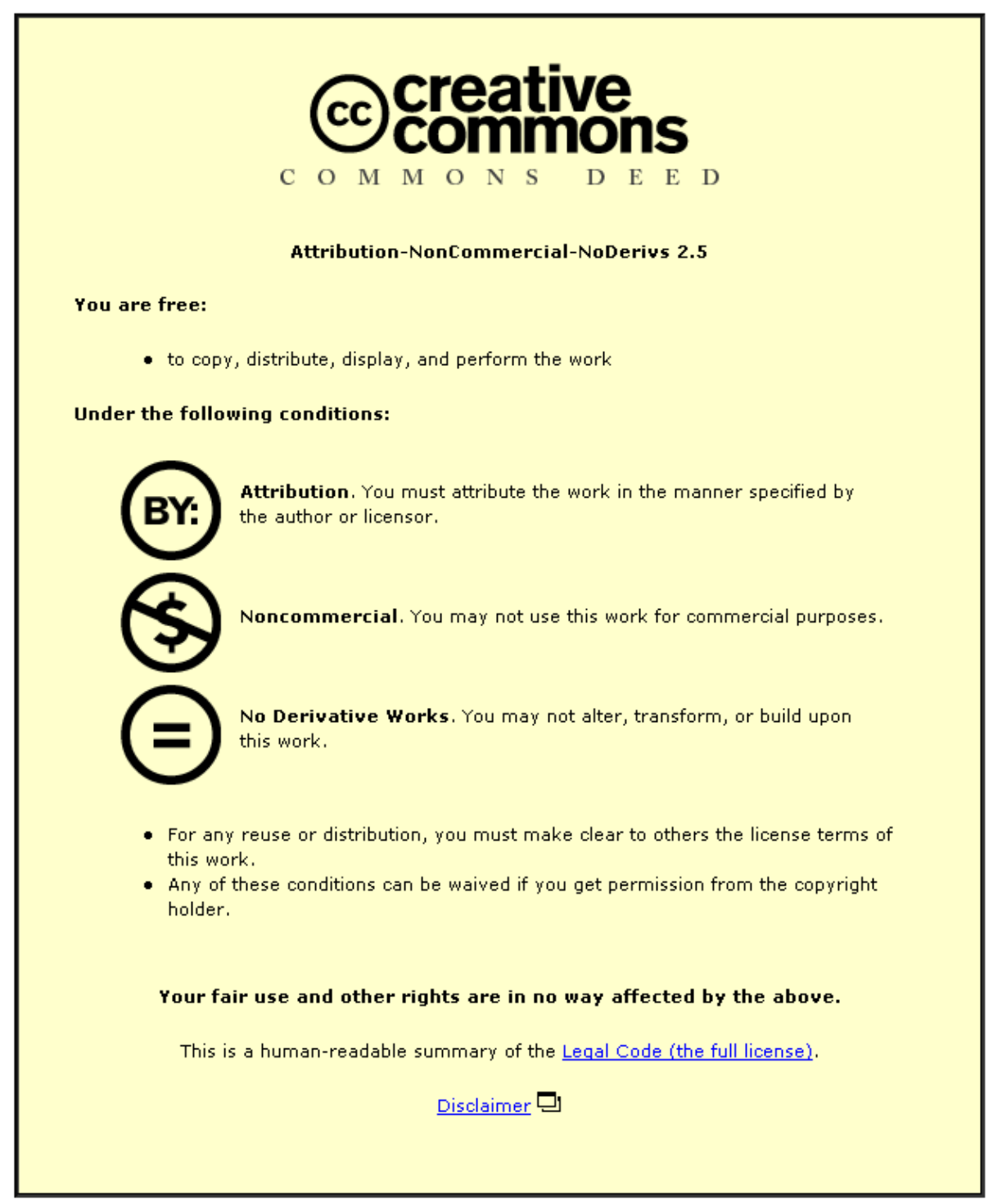

For the full text of this licence, please go to: http://creativecommons.org/licenses/by-nc-nd/2.5/ 


\title{
Evaluating the institutional sustainability of an urban water utility: a conceptual framework and research directions
}

\author{
Sam Kayaga* ${ }^{1}$, Josses Mugabi ${ }^{2}$ and William Kingdom ${ }^{2}$
}

\begin{abstract}
Institutional sustainability (IS) is critical to translating infrastructure investments into actual service delivery. This paper examines IS for urban water utilities, and how its progress could be tracked. Common conceptualisations of IS in extant literature were found inadequate from an evaluation standpoint. We conceptualize IS as a capacity rather than a financial issue, and, consistent with a processbased approach, we propose a new evaluation tool - the water utility maturity (WUM) model - which is flexible and considers different levels of IS. The WUM model, which requires further validation/verification, was piloted in two water utilities in South Asia with positive feedback.
\end{abstract}

Keywords: institutional capacity, institutional sustainability; maturity model; urban water utilities.

\section{Introduction}

Institutional sustainability is considered one of the yardsticks by which development interventions (including urban water supply projects) are evaluated. Over the past two decades, attempts have been made by various scholars to define institutional sustainability (e.g., Brinkerhoff and Goldsmith 1990; Ludwig et al. 1997; Brunckhorst, 1998; Pfahl, 2005; Hill, 2008) and to measure it (e.g. Norwegian Agency for Development 2000; Bell and Morse 2003; Edwards 2005; Litten 2005). But there is still no consensus on what institutional sustainability exactly means neither are there accepted and uncontested indicators to facilitate its evaluation.

While Multilateral Development Banks such as the World Bank, Asian Development Bank, African Development Bank and European Investment Bank desire institutional sustainability of the water and sanitation interventions they finance, few define it in operational terms. This paper examines the concept of institutional sustainability in an urban water utility context, and how progress could be tracked within a typical project/program. The paper is structured as follows. First, we briefly discuss how the concepts of institutions, institutional sustainability, institutional capacity and institutional capacity development have been defined in international development literature, and highlight an emerging conceptual framework for defining institutional sustainability as a capacity issue. Then, we summarize existing guidelines and tools for evaluating institutional sustainability in the water sector and other development interventions. Finally, the paper examines how these concepts can be applied to develop a more effective assessment tool for tracking a water utility's progress towards institutional sustainability.

\section{Methods}

This study was carried out in 2011 under the auspices of the World Bank, and consisted of a review of the literature and pilot studies conducted with two major urban water utilities in South Asia. The literature review sought to answer the following questions:

i. What are the different conceptualizations of institutional sustainability in the development literature?

ii. What are their shortcomings from the stand point of evaluation?

\footnotetext{
${ }^{1}$ Water, Engineering and Development Centre, Loughborough University, Leicestershire, LE11 3TU, UK

2 The World Bank, 1818 H Street NW, Washington DC 20433, USA

*Corresponding Author - Email: s.m.kayaga@Lboro.ac.uk
} 
iii. What sorts of indicators have been used by practitioners to evaluate institutional sustainability both for the development interventions and for urban water utilities specifically?

iv. What is the more promising framework for defining and evaluating institutional sustainability for urban water utilities?

We then synthesised the results of the literature review and developed a proposed approach for evaluating institutional capacity of water utilities. The draft evaluation framework was piloted with key informants in water utilities that provide water services to two major cities of South Asia.

\section{Institutions and institutional sustainability: conceptual debates}

Institutions and institutional sustainability are broad and complex concepts, with no precise definitions. The concepts are applied differently in various disciplines and theoretical traditions. Needless to say, a more detailed assessment of the meanings of the terms in the context of the water sector is critical to understanding how institutional sustainability can be evaluated. This section provides a brief review of how these key terms have been defined in the extant literature, and how they are conceptualised, adapted and applied in this paper.

\subsection{What are institutions?}

Literature is abounding with different but sometimes overlapping definitions of 'institutions' shaped by various philosophical and epistemological orientations. Using the analogy of a game, Aoki (2000) demonstrated how 'institutions' have been variously conceptualised, ranging from (i) players of the game; (ii) the rules of the game; or (iii) the outcome of the game, a rare conceptualisation that is mainly advanced by welfare economists. In line with the first orientation, some international development literature (e.g. Israel, 1987) has adopted the restrictive definition of 'institutions' to mean political or social organisations that are involved in policy making and implementation. However, a commonly used definition is captured by North (1990, p.3) who described institutions as '...the rules of the game in society or, more formally, the humanly devised constraints that shape human interaction'. Institutions could be formal, such as rules that human beings devise, or informal, such as conventions and codes of behaviour. They could be created, such as national constitutions, or they may evolve over time, such as a common law.

Other scholars have adopted both orientations (i.e. the role players and the rules) into their definition of institutions. For instance, Uphoff (1986, p.9) described institutions as 'complexes of norms and behaviours that persist over time by serving collectively valued purposes' which can either be diffusely practised or structured into organisations. Similarly, Brinkerhoff and Goldsmith (1992, p.371) defined institutions as '....rules or procedures that shape how people act, and roles or organisations that have attained special status or legitimacy'. Based on this conceptualisation, the level to which rules or roles are deeply rooted and highly esteemed by a large constituency is a measure of institutionalisation, a process through which organisations and roles acquire value and stability. This all-inclusive conceptualisation was also adopted by Spangenberg et al (2002), who defined institutions as the rules by which decision-making and implementation is structured - the rules could refer to social entities as actors, or systems of rules shaping behaviour. The social rules can be subdivided into three categories: (i) organisations as institutions (i.e. actors); (ii) institutional mechanisms; and (iii) institutional orientations. Organisations are the most tangible class of institutions. Organisations structure the choice of action of individual or corporate and other collective actors within a society.

Institutions could also be defined as mechanisms (i.e. explicit or formal systems of rules), or orientations (i.e. implicit or informal systems of rules) that structure the choices of actions of individual or collective actors in a society. It is important to note that organisations, mechanisms and orientations can all be described as systems of explicit or implicit rules. Along the conceptualisations by Uphoff (1986), Brinkerhoff and Goldsmith (1992) and Spangenberg et al, (2002), this paper adopts the all-inclusive view of institutions as rules and roles by which decision-making and implementation is structured, i.e. 
institutions as a combination of organisations (as actors), institutional mechanisms and institutional orientations.

\subsection{What is institutional sustainability?}

Institutional sustainability is defined in various ways in the development literature. A critical review of the literature identified five broad views. One of the earliest studies (Honadle and Van Sant, 1985) defines institutional sustainability as continuation of the benefit flows to the users/clients with or without the programmes or organisations that stimulated them in the first place. This conceptualisation, which is consistent with the project cycle model of development ${ }^{3}$, assumes institutional sustainability is to be assessed after the project has ended, which presents practical problems in predicting institutional sustainability during the project period (Brown, 1998).

Another school of thought defines institutional sustainability in terms of the longevity of the institution. The longer an organisation survives as an identifiable unit, the more institutionally sustainable it is considered to be (Brinkerhoff and Goldsmith, 1992). However, there are several flaws and inconsistencies with this conceptualisation (Brown, 1998): e.g. (i) how long does an organisation have to survive in order to qualify as sustainable? (ii) is survival of an organisation by itself enough, or should there be some minimum performance criteria for an institution to be considered sustainable? (iii) some organisations are set up to achieve a specific purpose, and longevity of such organisations may not be necessary or desirable; and (iv) it may be difficult to evaluate the sustainability of the institution ex-ante, during the implementation phase.

In the context of development management, institutional sustainability has also been defined as the ability of an organisation to meet recurrent costs, after donor funding is exhausted (Brown, 1998). Financial selfsufficiency definition may not necessarily apply to some developmental activities that require high capital costs, such as is the case for water source development to supply low-income communities in a waterscarce area. Financial self-sufficiency contributes to viability, which is a separate concept, although closely related to sustainability. It is clear that some desirable developmental activities will never be financially viable, as their capacity for full cost recovery is minimal or non-existent.

Increasingly, institutional sustainability is being conceptualised as a capacity issue, rather than a financial issue. Many reputable scholars and international development agencies currently define institutional sustainability as the capacity of an institution to generate a minimum level and quality of valued outputs over the long term (Brown, 1998; Brinkerhoff and Goldsmith, 1992; Pfahl, 2005). It is ‘...the institution’s capacity to coordinate human interaction in order to achieve specific sustainability objectives' (Pfahl, 2005, p.84). Institutional sustainability is about continued effectiveness, about creating and maintaining an acceptable level of capacity, and then about converting that capacity into actual performance.

Brinkerhoff and Goldsmith (1992) and Hill (2008) emphasized the dynamic and temporal character of institutional sustainability and conceive it as a process by which key features of sustainability have been institutionalized within a management regime. This school of thought considers institutional sustainability to be a process of internalizing normative and regulative structures and mechanisms that serve to reinforce system dynamics to produce and maintain desired outcomes that satisfy collective goals. This position is reinforced by Brown (1998), who states that learning is an essential ingredient of institutional sustainability. Learning is defined as the capacity of an organisation to accumulate knowledge from its own experiences, and disseminate it to its wide membership, reflecting on it and using it to adapt and cope with changes in the operating environment. Broadly speaking, learning determines the adaptive capacity of organisations, institutional mechanisms and orientations.

\footnotetext{
${ }^{3}$ This is an approach where a set of actions are designed and defined in advance, which are oriented to a specific development objective, and are represented by a logic model that links causes and effects from inputs to results. This type of development approach has sometimes been labelled as a blueprint approach, and usually does not encourage the participation of the development beneficiaries.
} 
Adapting the concepts by Brown (1998), Brinkerhoff and Goldsmith (1992), Hill (2008), and Pfahl, (2005), this paper conceptualises institutional sustainability as the capacity of institutions to continuously generate a minimum level and quality of valued outputs, and to prioritise learning for continuous improvement. This conceptualisation makes it easier to operationalise the abstract concept of institutional sustainability, and hence improve its measurement validity. It follows from the above that an evaluation of institutional sustainability is essentially an evaluation of institutional capacity. Based on this conceptual framework, the next section discusses the concepts of institutional capacity and capacity development.

\section{Institutional capacity and capacity development}

Over the past two decades, there has been growing emphasis on the importance of institutional capacity and its development in the urban water sector. Urban water projects of the 1960s and 1970s were primarily directed towards the provision of physical assets and infrastructure. Through the 1980s and 1990s there was a growing realization that in many cases such projects had not been entirely successful, and that they had often not yielded the expected benefits in terms of improved services. For instance, FairWater, a water and sanitation foundation recently estimated that there were over 50,000 dysfunctional water supply water points, in rural sub-Saharan Africa, worth about US\$300 million of capital investment (Skinner, 2009). The reasons for this shortfall were the generally poor technical, commercial and financial performance of service providers, caused by various factors, including unclear roles and responsibilities, limited autonomy and accountability, low cost recovery, lack of a commercial and customer orientation, and weak professional capacity.

In response, since the late 1990s, most international financing for infrastructural development also incorporate a component on institutional capacity development. For instance, an estimated US\$ 18 billion worth of water and sanitation projects financed by the World Bank over the past five years (2007-2011) have, on average allocated $15 \%$ of funds for improving the functioning of sector institutions. However, institutional capacity development can mean different things to different people, and it is used in a variety of situations without a rigorous attempt to understand what it means, and how progress could be measured. In the water utility context, institutional capacity development has previously been narrowly conceived in terms of individual skills development. Often missed were important dimensions at policy or legislative levels, or in supporting organisational processes and systems, structure and behaviours. This section briefly describes an emerging approach to institutional capacity development and how it relates to urban water utilities in particular.

\subsection{What is institutional capacity?}

Similar to the concepts of institutions and sustainability, capacity is defined in various ways by different entities. The concept of capacity has been ubiquitously applied by international development practitioners since the early 1990s, mainly in reference to 'absorption capacity' of the institutions receiving the development assistance. In this context, capacity emerged out of donor concerns for enhanced aid effectiveness, and referred to '...the ability of organisations to implement and manage projects, to exercise financial and product accountability..., to employ and train staff competent to undertake specific tasks, and to report on their work in ways which are acceptable to their donors' (Kaplan, 1999, p.16). Capacity has been described in the literature both as a process and an outcome; as dynamic and multidimensional. On the lower end of the spectrum, capacity as skills development and individual training is still a dominant perspective amongst some international development agencies and national governments (Baser et al, 2008). However, in the recent past, some international development agencies have adopted a more multidimensional definition of capacity. UNDP and Norwegian Development Co-operation (NORAD) have both defined capacity as the ability of individuals, institutions and broader societal systems to perform their functions effectively, efficiently and in a sustainable manner (NORAD, 2000; UNDP, 2007). This definition recognises that capacity depends not only on the capabilities of the people (i.e. the knowledge, skills and attitudes of the individuals, separately or as a group, and their competence to 
undertake responsibilities assigned to them) but also on the overall scope of the functions, the resources and tools needed to perform them, and the framework within which they are discharged.

Institutional capacity therefore goes beyond the individual and the organization. It encompasses the wider external operating environment (including policy, legal, political and regulatory aspects) which may facilitate or hamper the existence and performance of an organization. At the individual level, capacity refers to skills, experience and knowledge that are imparted to people to become efficient and effective actors in an organisation. Some of these capabilities are acquired through formal training, others through experiential learning. At the organizational level, capacity is seen in terms of how well an organization has developed a clear vision, mission and strategy; as well as adaptable systems, structures and tools; and the ability to influence its operating environment in a positive and strategic manner.

Other development practitioners have adopted a more endogenous definition. For instance, the Community Development Resource Association (CDRA) of South Africa defines capacity as '...the ability of an organisation to function as a resilient, strategic and autonomous entity' (Kaplan, 1999, p.17), which emphasizes the capacity of an entity to organise, rather than to perform particular tasks. CDRA's definition is rooted in the concept that an organisation or institution is an open system comprising of a number of features, which, individually as well as combined with the dynamics and harmony of the relationships between them, make up institutional capacity. Hence, institutional capacity emerges out of interaction of the institution's component parts, and is greater than the sum of abilities of the individual parts (ibid, 1999). The European Centre for Development Policy Management (ECDPM) has extended this concept and defined capacity as '...that emergent combination of individual competences and collective capabilities that enables a human system to create value' (Baser et al, 2008, p.34).

Similarly, the conceptual framework for capacity espoused by the United Nations Development Programme (UNDP) has evolved over time, and now UNDP defines capacity as the ability of individuals, institutions, and societies to perform functions, solve problems, and set and achieve objectives in a sustainable manner (UNDP, 2007). In its Capacity Assessment Framework, UNDP defines technical and functional capacities, the two types that are distinct, yet inter-related. Technical capacities are the 'hard skills' that are relevant for particular areas of expertise and practice in specific sectors. For instance in a water utility context, the relevant hard skills are those related to the engineering aspects of water and sanitation service provision. Functional capacities are 'cross-cutting' capacities required across various levels, which are not associated with specific sectors, key ones being the capacity to engage stakeholders; and the capacity to assess a situation and define a vision and mandate (UNDP, 2008).

\subsection{How does institutional capacity develop?}

The conceptualisation of capacity and capacity development has evolved at the same pace. At one time, capacity building was defined in relation to increasing the ability of organisations to implement and manage projects (Kaplan, 1999). Increasingly, international development agencies are emphasizing the long-term, endogenous and integrative aspects of capacity - how capacity develops over the long-term from within, rather than being externally-induced; and how it takes place at different levels. Hence capacity development is progressively being conceived as a process through which individuals, organisations and societies create, adapt, strengthen and maintain the capabilities to set and achieve their own development objectives over time (UNDP, 2008; EuroAid, 2009; OECD, 2006; NORAD, 2000).

One of the organisations that have taken a process-based approach to capacity development is the European Centre for Development Policy Management (ECDPM), which has recently carried out a multicountry research involving 16 case studies, to obtain a deeper understanding of how capacity develops, and the interrelationship between the concepts of capacity, organisational change and performance. ECDPM's conceptual framework recognises the importance of individuals' contributions to the institutional capacity in terms of skills, knowledge and competences, although they may not have an immediate linear, causal relationship with the overall capacity. Organisations are made up of people, and 
institutional capacity highly depends on complexities generated by interplay between individuals, and with the organisation as a human system (Baser et al, 2008; Kaplan, 1999).

The individual people's contributions are the soft competences, such as crafting relationships, trust and legitimacy, as well as the conventional 'hard' variety, such as technical, logistical and managerial skills. The individual contributions build up into collective (organisational) capabilities. A capability is defined as '.. the collective skill or aptitude of an organisation or system to carry out a particular function or process either inside or outside the system' (Baser et al, 2008, p.27). Capabilities are what the organisation or system applies to create the developmental value that members of society want.

Through an iterative analysis of the country case studies, the ECDPM identified and clarified the nature of five core capabilities, which together contribute to overall institutional capacity. Figure 1 shows the five core capabilities, which are described in the next paragraph.

Insert Figure 1 about here

The core capability to commit and engage in development activities is considered the most important, and enables an organisation or system to make conscious choices. This capability is about ownership, motivation, attitude and self-perception, which act together to energise all the other capabilities. Through empowerment, the organisation can create space and autonomy for independent action. This capability is a complex blend of motivation, power, legitimacy, confidence, security, meaning, values and identity and is the ability to motivate unwilling or unresponsive partners to plan, decide and engage collectively to exploit their other capabilities. The core capability to carry out technical, service delivery and logistical tasks includes the abilities to produce acceptable levels of performance; generate substantive outputs and outcomes; sustain production or services over time; and add value for their customers, clients, beneficiaries etc.(Baser et al, 2008).

The core capability to relate and attract resources and support is the ability to develop and manage beneficial relationships with external actors, so that the organisation can easily influence the acquisition of resources; create legitimacy; and deal effectively with competition, politics and power relations. The core capability to adapt and self-renew is the ability of the organisation or system to realise the need to understand and react to global and societal changes by pro-actively anticipating change and new challenges; adapting and modifying plans/operations based on monitoring of progress and outcomes; and developing resilience and coping with changing contexts. Finally, the core capability to balance diversity and coherence enables the leadership to manage a diverse set of capabilities, identities, interests and perspectives held by different people in the organisation; and to develop shared short- and long-term strategies and visions (Baser et al, 2008; Brinkerhoff and Morgan, 2010).

The five-capabilities model of capacity highlights the complexity and interconnectedness of the elements associated with capacity, and so the focus on separate components will not provide a sound basis for capacity development. This capacity emerges over time as follows: (i) as the system grows, it can handle more complex tasks more effectively; (ii) individual skills and competences grow in sophistication and diversity; (iii) core capabilities improve, become more varied, and get more institutionalised; (iv) the tangible and intangible assets and resources of the organisation grow in numbers and diversity; and (v) the collaboration and partnership with key external actors grows, enabling the enhancement of the institutional capacity (Baser et al, 2008; Brinkerhoff and Morgan, 2010).

The lessons to be drawn from ECDM's research on institutional capacity development may be summarised as follows:

- There is no single factor that can by itself explain capacity development. Capacity emerges from the complex interactions among all actors in the institution's system. 
- The capacity development process should have ownership, which should never be taken for granted. It needs to be negotiated, mediated, and supported during the process.

- The five capabilities model provides an approach for exploring organisational capacity and highlights informal and intangible aspects of capacity that can influence behavior.

- Capacity development should be approached more as a process of experimentation and learning, than the performance of predetermined activities.

- External interveners can facilitate capacity development, but cannot drive the process.

- Capacity development and performance should be considered as separate development outcomes which are related but not through a direct causal link.

\section{Evaluation of institutional capacity as a leading indicator of institutional sustainability}

A review of the literature presented in sub-section 3.2 shows that in the immediate past, many practitioners and scholars conceptualised institutional sustainability as an abstract attribute, which presented practical difficulties for monitoring and evaluating the progress towards sustainability. However, one school of thought regards institutional sustainability as a capacity issue, implying that an evaluation of institutional sustainability is essentially an evaluation of institutional capacity and its development over time. The discussion in section 4 above provided a good conceptual basis for evaluation of institutional capacity.

Now we look at existing tools in the literature and see how they measure up to the conceptual framework, identify weakness and propose a new way forward. The next sub-sections summarise the key existing methods and guidelines for evaluating institutional capacity as applied in the water sector, or the wider international development field, and draws relevant lessons for specific application to urban water utilities. The evaluations are categorized into three sections: those specific for water utilities; those designed for the water sector in general; and those in the wider international development sector.

\subsection{Evaluation guidelines designed for water utilities}

Table 1 shows a summary of reviewed evaluation tools and guidelines that have been applied to water utilities. The first three evaluation guidelines are using a similar conceptual framework for evaluating institutional capacity, which considers integrated capabilities of individuals, organisations and broader systems in the external environment. These guidelines, in varying details, can be used as diagnostic tools for performance improvements, identifying aspects for reform, and change management tools for implementing the reforms. However, the guidelines are designed to evaluate institutional capacity at one point in time, rather than for tracking the capacity development process. Another shortcoming is the guidelines' lack of emphasis on organisational learning and continuous improvement. The scope of the fourth guideline, the WIKTI tool, considers narrower aspects of capacity, focusing on skills transfer for improving operational efficiency and effectiveness. 
Table 1: Summary of existing tools and guidelines for evaluating institutional capacity of water utilities

\begin{tabular}{|c|c|c|c|}
\hline $\begin{array}{l}\text { Author, Date and } \\
\text { Title }\end{array}$ & Dimensions & $\begin{array}{l}\text { Measurement } \\
\text { instrument }\end{array}$ & Comments/ Remarks \\
\hline $\begin{array}{l}\text { 1. Cullivan et al } \\
\text { (1988) Guidelines } \\
\text { for Institutional } \\
\text { Assessment - Water } \\
\text { and Wastewater } \\
\text { Institutions, Water } \\
\text { and Sanitation for } \\
\text { Health Project }\end{array}$ & $\begin{array}{l}\text { - Organisational autonomy } \\
\text { - Leadership } \\
\text { - Management and admin } \\
\text { - Commercial orientation } \\
\text { - Consumer orientation } \\
\text { - Technical capacity } \\
\text { - Developing and maintaining staff } \\
\text { - Organisational culture } \\
\text { - Interactions with key external } \\
\text { institutions }\end{array}$ & $\begin{array}{l}\text { Each dimension has a } \\
\text { detailed set of indicators } \\
\text { scored on a Likert scale; } \\
\text { The assessment is to be } \\
\text { carried out by a multi- } \\
\text { disciplinary team from } \\
\text { international donor } \\
\text { agencies, using a variety } \\
\text { of data collection methods }\end{array}$ & $\begin{array}{l}\text { It measures institutional } \\
\text { capacity; } \\
\text { It has practical guidelines } \\
\text { for data collection; } \\
\text { It has been widely applied } \\
\text { as a diagnostic tool; } \\
\text { Also assesses output } \\
\text { measures. }\end{array}$ \\
\hline $\begin{array}{l}\text { 2. Baietti, Kingdom } \\
\text { and van Ginneken } \\
\text { (2006) } \\
\text { Characteristics of } \\
\text { well performing } \\
\text { public water utilities }\end{array}$ & $\begin{array}{l}\text { - Degree of external autonomy } \\
\text { - External accountability for results } \\
\text { - Internal accountability for results } \\
\text { - Decentralization of responsibilities } \\
\text { - Market Orientation } \\
\text { - Customer Orientation } \\
\text { - Corporate Culture } \\
\text { - Performance indicators }\end{array}$ & $\begin{array}{l}\text { Provides an analytical } \\
\text { framework with multiple } \\
\text { guiding questions }\end{array}$ & $\begin{array}{l}\text { It is in form of Water } \\
\text { Working Notes for the } \\
\text { World Bank \& builds on } \\
\text { field experience; } \\
\text { The guideline is well } \\
\text { illustrated with case studies } \\
\text { of well performing water } \\
\text { utilities. }\end{array}$ \\
\hline $\begin{array}{l}\text { 3. Locussol and van } \\
\text { Ginneken (2008) } \\
\text { Template for } \\
\text { assessing the } \\
\text { governance of } \\
\text { public water supply } \\
\text { and sanitation } \\
\text { service providers }\end{array}$ & $\begin{array}{l}\text { - Overall Policy environment } \\
\text { - Functioning of WSS Service Provider } \\
\text { - Development of the WSS Infrastructure } \\
\text { - Operation of the WSS Service } \\
\text { - Financing of the WSS Infrastructure } \\
\text { - Economic regulation of the WSS } \\
\text { Service }\end{array}$ & $\begin{array}{l}\text { There are descriptive } \\
\text { notes and several } \\
\text { attributes for each } \\
\text { dimension. } \\
\text { The summary assessment } \\
\text { matrices shows the } \\
\text { existence of the structures } \\
\text { and procedures, and if so, } \\
\text { how their quality is rated }\end{array}$ & $\begin{array}{l}\text { This assessment template } \\
\text { complements IBNET } \\
\text { metric benchmarking; } \\
\text { Authors recommend that } \\
\text { the ratings are validated } \\
\text { through group discussions; } \\
\text { The template was field- } \\
\text { tested in Benin, Guinea and } \\
\text { Togo. }\end{array}$ \\
\hline $\begin{array}{l}\text { 4. Suez } \\
\text { Environment (2010) } \\
\text { The Water } \\
\text { International } \\
\text { Knowledge Transfer } \\
\text { Initiative (WIKTI) }\end{array}$ & $\begin{array}{l}\text { - } 10 \text { Drinking water processes } \\
\text { - } 10 \text { Wastewater treatment processes } \\
\text { - } 9 \text { Customer services processes } \\
\text { - } 9 \text { Crosscutting management processes }\end{array}$ & $\begin{array}{l}\text { A system of business } \\
\text { benchmarks based on } \\
\text { objective criteria, for each } \\
\text { of the processes } \\
\text { Regular assessments done } \\
\text { to establish progress }\end{array}$ & $\begin{array}{l}\text { A methodology developed } \\
\text { to transfer knowledge and } \\
\text { skills of an international } \\
\text { operator to local staff; } \\
\text { Initial diagnosis, and target } \\
\text { maturity level defined for } \\
\text { contract period. }\end{array}$ \\
\hline
\end{tabular}

\subsection{Evaluation guidelines used for generic water sector institutions}

The tools and guidelines described in Table 2 are not explicit on what they were evaluating, whether institutional capacity or performance. Even where an attempt was made to measure sector performance, there was no measurement instrument provided, or it was overly generic. Furthermore, owing to the complexity of evaluating institutional capacity or performance at the sector level, there was no commonality in the conceptualisation of the terms, the methodology used or the dimensions adopted. This pattern reflects methodological difficulties of devising an evaluation framework for large, complex systems, and supports a parsimonious approach of evaluating institutional capacity at the utility, rather than sector level.

Table 2: Summary of existing tools and guidelines for evaluating institutional capacity in the water sector

\begin{tabular}{|c|c|c|c|}
\hline $\begin{array}{l}\text { Author, Date and } \\
\text { Title }\end{array}$ & Dimensions & $\begin{array}{l}\text { Measurement } \\
\text { instrument }\end{array}$ & Comments/ Remarks \\
\hline $\begin{array}{l}\text { 1. Saleth, M. and } \\
\text { Dinah, A. (2004) The } \\
\text { Institutional } \\
\text { Economics of Water: } \\
\text { Across-country } \\
\text { Analysis of }\end{array}$ & $\begin{array}{l}\text { - Water law } \\
\text { - Water Policy } \\
\text { - Water Administration } \\
\text { - Exogenous factors } \\
\text { Political, legal, demographic, } \\
\text { economic, and resources factors }\end{array}$ & $\begin{array}{l}\text { Detailed questionnaire } \\
\text { on decomposed } \\
\text { institutional aspects } \\
\text { with their respective } \\
\text { finer aspects; }\end{array}$ & $\begin{array}{l}\text { Uses an institutional transaction } \\
\text { cost framework to establish } \\
\text { institutional inter linkages and } \\
\text { their effect on sector } \\
\text { performance; }\end{array}$ \\
\hline
\end{tabular}




\begin{tabular}{|c|c|c|c|}
\hline $\begin{array}{l}\text { Institutions and } \\
\text { Performance (WB) }\end{array}$ & - Overall sector performance & $\begin{array}{l}\text { Use of regression } \\
\text { analysis }\end{array}$ & $\begin{array}{l}\text { Validated with cross-country } \\
\text { data from } 11 \text { countries }\end{array}$ \\
\hline $\begin{array}{l}\text { 2. AMCOW et al } \\
\text { (2006) Getting Africa } \\
\text { on track to meet the } \\
\text { MDGs on water \& } \\
\text { sanitation: A status } \\
\text { overview of sixteen } \\
\text { African countries } \\
\text { (CSO1) }\end{array}$ & $\begin{array}{l}\text { Assessing level of preparedness for } \\
\text { achieving MDGs concerning: } \\
\text { - National strategies } \\
\text { - Institutional arrangements } \\
\text { - Sector financing } \\
\text { - Sector monitoring and evaluation } \\
\text { - Sector capacity }\end{array}$ & $\begin{array}{l}\text { Analysis of local data } \\
\text { sources \& broad-based } \\
\text { consultation with lead } \\
\text { government agencies } \\
\text { and country sector } \\
\text { stakeholders; } \\
\text { No measurement } \\
\text { instruments provided }\end{array}$ & $\begin{array}{l}\text { Report also provides a } \\
\text { sustainability scorecard of } \\
\text { success factors with regard to } \\
\text { institutional and financial } \\
\text { sustainability for the whole } \\
\text { sector and the subsectors }\end{array}$ \\
\hline $\begin{array}{l}\text { 3. AMCOW et al } \\
\text { (2011) AMCOW } \\
\text { Country Status } \\
\text { Overviews: Pathways } \\
\text { to Progress (CSO2) }\end{array}$ & $\begin{array}{l}\text { - Enabling pillar } \\
\text { Policy; Planning; Budget } \\
\text { - Developing pillar } \\
\text { Expenditure; Equity; Output } \\
\text { - Sustaining pillar } \\
\text { Maintenance, Expansion, Extent, } \\
\text { use and quality of improved water } \\
\text { services } \\
\text { Markets for, Uptake \& Use of } \\
\text { sanitation services }\end{array}$ & $\begin{array}{l}\text { Detailed multiple } \\
\text { indicators for each of } \\
\text { the sub-dimensions, and } \\
\text { respective descriptions } \\
\text { of the response options } \\
\text { for a high score }(1) \text {, a } \\
\text { medium score }(0.5) \text { or a } \\
\text { low score }(0)\end{array}$ & $\begin{array}{l}\text { Scorecards were developed, and } \\
\text { priority actions identified for } \\
\text { each sub-sector in } 30 \text { countries; } \\
\text { Country scorecard results were } \\
\text { compared, and regional } \\
\text { performance indicators } \\
\text { computed for each dimension. }\end{array}$ \\
\hline $\begin{array}{l}\text { 4. Gandhi, V., Crase, } \\
\text { L. and Roy, A. } \\
\text { (2009) Institutional } \\
\text { Analysis of the } \\
\text { Performance of } \\
\text { Water Institutions in } \\
\text { Three Major States of } \\
\text { India }\end{array}$ & $\begin{array}{l}\text { - Clarity of objectives } \\
\text { - Quality of interaction among } \\
\text { constituents and between } \\
\text { institutions } \\
\text { - Level of adaptability to internal and } \\
\text { external changes } \\
\text { - Appropriateness of scale with } \\
\text { respect to scope and size } \\
\text { - Compliance to rules and procedures } \\
\text { of the institution }\end{array}$ & $\begin{array}{l}\text { Key informant } \\
\text { interviews with } 29 \text { local } \\
\text { irrigation institutions } \\
\text { and questionnaires to } \\
450 \text { sampled } \\
\text { beneficiary households; } \\
\text { Data treated with } \\
\text { ANOVA, regression } \\
\text { and factor analyses. }\end{array}$ & $\begin{array}{l}\text { Analysis of institutional } \\
\text { performance was based on the } \\
\text { 'New Institutional Economics' } \\
\text { concept that a well-performing } \\
\text { institution aims to reduce both } \\
\text { the transformation and } \\
\text { transaction costs of various } \\
\text { activities. }\end{array}$ \\
\hline
\end{tabular}

\subsection{Evaluation guidelines used for generic international development interventions}

All the five evaluation frameworks summarised in Table 3 highlight the importance of factors in the external and internal environments in shaping the capacity of an organisation. All but one framework provide measurement instruments with detailed multiple-attribute criteria, which are generic, but may easily be adapted for urban water utilities. However, the measurement instruments are designed to be used for evaluating the capacity at a snapshot.

Table 3: Summary of existing tools and guidelines for evaluating institutional capacity in generic international development interventions

\begin{tabular}{|c|c|c|c|}
\hline $\begin{array}{l}\text { Develop. Agency, Date } \\
\text { and Title }\end{array}$ & Dimensions & $\begin{array}{l}\text { Measurement } \\
\text { instrument }\end{array}$ & Comments/ Remarks \\
\hline $\begin{array}{l}\text { 1. Lusthaus et al (1995) } \\
\text { Institutional assessment. } \\
\text { International } \\
\text { Development Research } \\
\text { Centre (Canada). }\end{array}$ & $\begin{array}{l}\text { - Key forces in the external environment } \\
\text { - Organizational motivation } \\
\text { - Organizational capacity } \\
\text { - Organizational performance }\end{array}$ & $\begin{array}{l}\text { Dimensions are } \\
\text { decomposed into sub- } \\
\text { dimensions, each with } \\
\text { detailed, multiple } \\
\text { guiding questions }\end{array}$ & $\begin{array}{l}\text { The evaluation tool was } \\
\text { designed for assessing } \\
\text { capacity of research } \\
\text { institutions, but easily } \\
\text { adaptable for water utilities }\end{array}$ \\
\hline $\begin{array}{l}\text { 2. Norwegian } \\
\text { Development Agency } \\
\text { (NORAD), (2000) } \\
\text { Handbook in } \\
\text { Assessment of } \\
\text { Institutional } \\
\text { Sustainability. }\end{array}$ & $\begin{array}{l}\text { - Organizational strategy } \\
\text { - Organizational management } \\
\text { - Financial resources } \\
\text { - Infrastructure } \\
\text { - Performance } \\
\text { - Competence } \\
\text { - Culture and communication } \\
\text { - Linkages and networks } \\
\text { - Legal and political framework } \\
\text { - External cultural framework } \\
\text { - Participation and legitimacy }\end{array}$ & $\begin{array}{l}\text { Two instruments are } \\
\text { provided: (i) a rapid } \\
\text { assessment checklist, } \\
\text { each dimension with } \\
\text { several attributes } \\
\text { scored 0-3; (ii) sub- } \\
\text { dimensions created, } \\
\text { each with more in- } \\
\text { depth multiple- } \\
\text { attribute checklist }\end{array}$ & $\begin{array}{l}\text { The framework uses broad } \\
\text { and generic statements, } \\
\text { which could be applied to a } \\
\text { wide range of organizations } \\
\text { supported by NORAD; } \\
\text { NORAD recommends } \\
\text { several institutional } \\
\text { assessments during the } \\
\text { project life cycle }\end{array}$ \\
\hline
\end{tabular}




\begin{tabular}{|c|c|c|c|}
\hline $\begin{array}{l}\text { 3. UK Dept for } \\
\text { International } \\
\text { Development (DFID), } \\
\text { (2003) Promoting } \\
\text { Institutional \& } \\
\text { Organisational } \\
\text { Development }\end{array}$ & $\begin{array}{l}\text { - Strategic and institutional environment } \\
\text { - Financial resources and systems } \\
\text { - Role and strategy } \\
\text { - Organizational and national culture } \\
\text { - People \& Human Resource } \\
\text { Management } \\
\text { - Management systems and practices } \\
\text { - Organizational structures } \\
\text { - Outputs/performance }\end{array}$ & $\begin{array}{l}\text { The Open Systems } \\
\text { Model (OSM) } \\
\text { provides sub- } \\
\text { dimensions and } \\
\text { detailed checklists for } \\
\text { evaluating each of the } \\
\text { sub-dimensions }\end{array}$ & $\begin{array}{l}\text { The source book presents } \\
\text { other diagnostic tools to be } \\
\text { used with OSM, e.g. 7-S; } \\
\text { SWOT analysis; } \\
\text { Organizational Elements } \\
\text { Model; Risk Management } \\
\text { Matrix; EFQM Excellence } \\
\text { Model; Force Field } \\
\text { Analysis; Burke Litwin } \\
\text { Model ; Benchmarking. }\end{array}$ \\
\hline $\begin{array}{l}\text { 4. EuropeAid, the } \\
\text { European Commission, } \\
\text { (2009)Toolkit for } \\
\text { Capacity Development }\end{array}$ & $\begin{array}{l}\text { - Operating environment } \\
\text { - Clarity of results, mandate \& purpose } \\
\text { - Adequacy of resources } \\
\text { - Organization, management and } \\
\text { infrastructure } \\
\text { - Organizational culture and values } \\
\text { - Vision and leadership } \\
\text { - Attitude to change } \\
\text { - Monitoring mechanisms }\end{array}$ & $\begin{array}{l}\text { There is matrix that } \\
\text { provides multi-item } \\
\text { criteria for each } \\
\text { dimension, with a 1-5 } \\
\text { scoring system; and a } \\
\text { provision for } \\
\text { indicating trend }\end{array}$ & $\begin{array}{l}\text { This quick capacity } \\
\text { scanning matrix is } \\
\text { reinforced by a detailed } \\
\text { checklist for capacity } \\
\text { assessment to identify } \\
\text { critical issues important for } \\
\text { subsequent capacity } \\
\text { development }\end{array}$ \\
\hline $\begin{array}{l}\text { 5. Kimata (2008) } \\
\text { Capacity Assessment } \\
\text { for Enhancing } \\
\text { Development, Japanese } \\
\text { International } \\
\text { Development Agency } \\
\text { (JICA). }\end{array}$ & $\begin{array}{l}\text { - Organizational capacities } \\
\text { Technical capacities } \\
\text { Core capacities } \\
\text { - Factors in the enabling environment } \\
\text { Social-cultural, policy, and institutional } \\
\text { framework }\end{array}$ & $\begin{array}{l}\text { No measurement } \\
\text { instrument provided }\end{array}$ & $\begin{array}{l}\text { The document } \\
\text { recommended the use of an } \\
\text { evaluation tool developed } \\
\text { by Berryman S. et al (1997) } \\
\text { Guidelines for Assessing } \\
\text { Institutional Capacity, The } \\
\text { World Bank. }\end{array}$ \\
\hline
\end{tabular}

\section{Limitations of existing evaluation frameworks and guidelines}

The previous section shows that institutional capacity has been evaluated in various ways, depending on the conceptual framework being applied. The guidelines were presented into three categories: those specifically developed for water utilities (summarised in Table 1); those applied in the water sector (summarised in Table 2); and those that have been used by international development agencies to evaluate the institutional sustainability of various development-related interventions in different sectors (summarised in Table 3).

Of the four tools shown in Table 1, the WIKTI tool is unique, as it considers a narrower scope of institutional capacity, i.e. operational effectiveness and efficiency. The rest of the guidelines listed in Table 1 evaluate institutional capacity at various levels, i.e. at the individual, organisational and the wider operating environment. A similar scope is adopted by various international development agencies, as summarised in Table 3.

Conversely, the evaluation guidelines shown in Table 2 do not differentiate between internal and external environments, as their units of analysis are the whole water sector environment, making the assessment much too broad, unfocused and relatively ineffective. As a result, there are hardly any practical lessons that can be drawn from these guidelines, to be applied for evaluating institutional capacity of water utilities.

Most of the existing evaluation tools and guidelines described in Section 5 are not designed for organisational/ institutional self -evaluation, and they do not emphasise organisational learning. Instead they are designed by donor agencies to guide their staff or consultants in carrying out evaluations prior to, during or at the end of a donor-supported institutional development initiative. Organizational learning (which leads to continuous improvement) is more likely to be realized using models that allow for selfassessment rather than donor-driven evaluations. Furthermore, these guidelines are designed to evaluate the institutional capacity at one point in time (at a snapshot); they do not have a provision for monitoring improvements of institutional capacity over time, nor are they amenable to benchmarking. 
These limitations are inherent in the approach adopted by the authors which assumes that institutional capacity may be developed and driven by external forces, in most cases according to the agenda of the international donor agencies. The inherent assumption is that institutional capacity may be developed by constructing and adjusting the capacity of people, organisations and systems, through a purposeful and planned intervention. On the contrary, ECDPM's approach is based on the premise that organisations and systems are social or human systems that evolve organically in unpredictable ways, and hence their capacity emerge from a complex and difficult-to-chart process of organisational learning and adaptation. Although this capacity, which emerges from complex interactions among all actors in the system cannot be fully controlled by external forces, the process of change can be studied, understood and influenced (Land et al, 2009).

Another important limitation of the existing evaluation guidelines is their inconsistency with the emerging conceptualisation of institutional capacity, with respect to dealing with factors in the organisation's external environment. The guidelines envisage a passive organisation operating in a given context, for which 'conduciveness of the external environment' is evaluated. On the contrary, as discussed in section 3.2, the framework for institutional capacity development envisages an organisation that '....is able to strategize and prioritise ...takes full responsibility for its own circumstances and believes that it can impact and affect those circumstances' (Kaplan, 1999, p.18). Studies and experience shows that high performing utilities in developing countries actively seek to influence the external environment both positively and strategically (Cullivan et al, 1988; Muhairwe, 2009). In ECDPM's conceptual framework, an organisation is expected to influence the external environment through all the five core capabilities, especially through: (i) the capability to manage relationships, mobilise resources, network, build legitimacy, and protect their operating space; (ii) the capability to learn, strategize, adapt, reposition, and manage change; (iii) the capability to carry out core functions directed at the implementation of mandated goals; and (iv) the capability to encourage innovation and stability, manage complexity, and balance capability mix.

The above limitations suggest a need for a more robust guideline for evaluating institutional capacity of water utilities. The guideline should be grounded into the emerging conceptualisation of institutional capacity, be specific to water utilities, and draw on modern management concepts and a growing body of knowledge on the determinants of institutional sustainability of urban water utilities in developing countries. The next section draws on these ideals and adapts the dimensions from the reviewed evaluation guidelines to develop a model for monitoring and evaluating institutional capacity of urban water utilities.

\section{Developing a water utility maturity model}

This paper proposes a new evaluation model rooted in the emerging conceptualisation of institutional capacity and modern management concepts. The Water Utility Maturity (WUM) model is based on the premise that although external assistance is important to the process of institutional capacity development, is only one of drivers: sustainable institutional capacity emerges through endogenous processes led by local actors, and that it is a long-term process, not an event. The model therefore considers different levels of institutional capacity referred to as maturity levels. Since the early 1990s, capability maturity models have been proposed for various organisational capacities, such as project management, supplier relationships, research and development effectiveness, business process management, maintenance management, construction industry, strategic management, risk management and knowledge management (Maier et al, 2009). Capability maturity may be defined as "the extent to which an organization has explicitly and consistently deployed processes that are documented, managed, measured, controlled, and continually improved” (Cooke-Davies, 2005).

An important strength of maturity models is their ability to monitor the progress in a stepwise and longitudinal development of institutional capacity. Another key strength is their flexibility: an assessment framework can be developed to take into account the specific needs of an organisation. Hence, key 
process areas can be as diverse and detailed as necessary. The maturity model can be designed to be descriptive (i.e. for only assessing the as-is situation); prescriptive (i.e. provides emphasis on the relationships to business performance and develops a roadmap to improvement); or comparative (i.e. also enables benchmarking across industries or regions). This diversity also provides flexibility in terms of the scope and focus of the model; design methods; number of maturity levels; number of components; extent of maturity model layers; and whether it is staged or continuous. For this reason, maturity models need to be developed from scratch, requiring a significant investment into a scientific and rigorous process. Furthermore, the maturity grid should strike a balance between an often complex reality and the simplicity of the underlying model (Maier et al, 2009).

\subsection{Outline of the WUM model and its administration}

Most maturity models reviewed focus on processes for specific capacities of an organisation. The proposed WUM model is generic and evaluates a water utility in terms of five broad dimensions of institutional capacity: (i) behaviour; (ii) structure/processes; (iii) capabilities; (iv) organisational tools; and (v) influence. These dimensions are integrative, mutually exclusive and collectively exhaustive - they were selected based on the synthesis of the reviewed literature summarised in the previous sections and personal experience of the authors. Each dimension is defined by several attributes, as shown in Figure 2. For instance, the dimension of organisational behaviour is defined by the attributes of strategic orientation, strategic leadership, customer orientation and commercial orientation.

Insert Figure 2 about here

For each attribute shown in Figure 2, five maturity levels were defined. In the WUM model, maturity levels represent distinct cumulative stages ( 1 being the lowest stage and 5 being the highest), where higher stages build on the requirements of lower stages. Maturity in this model is evaluated by the degree to which business processes and management systems are structured and institutionalised in the water utility (Maier et al, 2009). We have developed defining labels for each maturity level corresponding to the desirable condition of the attributes in the specific level. These definitions are distinct and as clear as possible, so as to enhance interpretation of the results. For example, Figure 3 shows a graphical presentation of the maturity progression for the attribute of strategic orientation, under the dimension of 'Behaviour'. At level 1, the utility is largely reactive to the business environment. As it matures, strategies are developed, institutionalised and becomes continuously adaptive to market conditions, and the major stakeholders beneficially organised around the utility's processes. In essence, the complete WUM model is composed of 115 cells of defining labels (i.e. 5 maturity levels for 23 attributes), but is not presented in this paper because of space limitations.

Insert Figure 3 about here

The mechanism for administering the WUM model depends on the aim of the assessment and the resources available for conducting the assessment. The model could be used for self-assessment to capture the perceptions of the utility's staff, or facilitated by a consultant. For a process largely aimed at benchmarking, the model could be administered in form of a questionnaire, so that it may reach a wide variety and a large number of respondents. However, for the purpose of raising awareness and improving performance, interviews and/or group discussions are preferable. Group-administered workshops are usually more process-focused, provide a high response rate, minimise single-respondent biases, and create common reference points, which facilitates interpretation of the resulting scores (Maier et al, 2009). We 
have also developed an aggregated WUM model that is suitable for rapid self-assessments by senior management. The outputs of such a self-assessment could be incorporated into a service improvement programme. Annex 1 provides a draft aggregated model, which provides defining labels, in aggregated terms, for the broad dimensions of behaviour, structure/processes, capabilities, tools and influence.

\subsection{Potential applications of the WUM model}

The WUM model has a number of potential applications. The model provides a common language and a shared vision, and enables the identification of capacity development interventions, through a systematic process of assessment, using a holistic framework that covers the entire organisation. It can thus provide an inventory of current capabilities and identify a baseline for measuring institutional capacity development. Secondly, the model may integrate existing and planned institutional development activities, hence improving efficiency and effectiveness. Thirdly, the WUM model may elicit different perspectives, stimulate reflection, and lead to rethinking a utility’s management system, philosophy and focus. Fourthly, the WUM model highlights the need for change and fosters a culture for excellence. Fifthly, the model may provide a guide for decision-making, and aid identification of areas for improvement. Lastly, the WUM model can be used to benchmark institutional sustainability and provide an opportunity to translate internal assessment data directly into the formats used by international quality standards such as ISO 9001.

The proposed WUM Model was piloted in February 2012 to assess the institutional capacity of the two large urban water utilities in South Asia. Consultants carried out review of key operational and policy documents, informant interviews, focus group discussions, and observations, which enabled a holistic assessment of the maturity levels for the various attributes contributing to institutional capacity. The perceived maturity levels, which were aggregated into scores for five dimensions of behaviour, structure and processes, technical capabilities, tools and influence, were plotted as a radar diagram, shown in Figure 6.2. A focus group discussion with senior managers of one of the utilities provided positive feedback on the face and content validity of the model, with the following key suggestions for further improvements:

- The attributes describing the maturity levels need to be refined, in order to obtain a more accurate positioning of the utility;

- For some dimensions, it was difficult to plot the maturity level of the utility, based on the aggregated diagnostic characteristics - these need to be revisited; and

- The quantitative assessment of performance needs to be strengthened under the dimension of 'Capabilities'.

Insert Figure 4 about here

The preliminary and rapid assessment showed that the two utilities are operating below Maturity Level Three. While Utility B's behaviour and tools are perceived to be close to a 'proactive' maturity level, it is being pulled down by the low level of influence and inefficient organisational structure and processes. On the other hand, Utility A is perceived to be stagnating at the basic level for all the five dimensions. These findings were presented to, and discussed with Utility A's senior management, who appreciated and concurred with most results. However, there is need to carry out further studies in which the model is used as a self-assessment tool by utility staff and other key stakeholders, so that enough responses could be populated for carrying out various validity and reliability diagnostic tests of the tool. 
More work is required to develop this model. The contents describing the various attributes are merely indicative and need to be confirmed. Further exploratory and empirical work is needed. We identify the following steps to be taken in order to further develop the model:

1. Confirming the model structure (levels, attributes and defining labels) and validity through further empirical work;

2. Increasing the model's flexibility in terms of its scope, e.g. both a diagnostic tool and a benchmarking tool, and in its mode of administration - e.g. through self-assessment, third party assisted assessments or by a certified practitioner;

3. Creating diagnostic tools to evaluate the characteristics under each maturity level;

4. Creating analytical tools to assist in interpretation of data;

5. Identifying barriers to progressing between maturity levels;

6. Identifying enablers to overcome barriers;

7. Creating generic 'institutional capacity development strategies and plans' for moving between maturity levels; and

8. Perform pilot applications of the model, reviewing and modifying if necessary

The WUM model development and testing process needs to be carried out in coordination with various regional/international water industry professional associations and water operator/utility networks (e.g. International Water Association, African Water Association and Global Water Operators Partnerships), and should include the identification of feasible arrangements and resource commitments for maintaining the model's growth and its use as an industry standard. The World Bank's Water Practice could play the role of coordinating the model's development, while regional utility networks could promote the model's use.

\section{Summary and Conclusion}

This paper examined the different conceptualizations of institutions, institutional sustainability, institutional capacity and institutional development in the international development literature and how they could be adapted for evaluation of institutional development interventions in the urban water sector. As a starting point, we adopted the rule-and-role conceptualisation that is popular with social scientists, which defines institutions as a combination of organisations (as actors), institutional mechanisms and institutional orientations. This definition recognises that water utilities are organisational institutions (actors), which operate under, and are constrained by, the overall legal and institutional environment (rules). Similarly, institutional sustainability was defined differently by various scholars, and some of the conceptualisations rendered its evaluation practically difficult. To avoid this pitfall, we adopted the position which considers institutional sustainability as a capacity issue, and defined institutional sustainability as the capacity of institutions to continuously generate a minimum level and quality of valued outputs, and to prioritise learning for continuous improvement.

The approach for implementing institutional capacity development has evolved over time, and currently, the emphasis of many international development agencies is the endogenous aspect of institutional capacity, i.e. how capacity develops from within the institution, rather than being driven by outsiders; and how it develops amidst an uncertain and unpredictable operating environment. This paper adopted ECDPM's approach which identifies five core capabilities that enable an institution to perform and survive in a turbulent operating environment: the capabilities to commit and engage; to carry out technical, 
service delivery and logistical tasks; to relate and attract resource and support; to adapt and self-renew; and to balance coherence and diversity.

We applied the concepts from ECDPM's approach to the elements of tools/guidelines for evaluating institutional capacity discussed in international development literature, and developed an evaluation model for measuring and tracking of institutional capacity, and by extension, institutional sustainability for urban water utilities. We consider institutional sustainability to be synonymous with institutional maturity, which is based on a process-based approach to management. The Water Utility Maturity (WUM) model we have proposed builds on the concept of institutional maturity, and draws from the strengths of evaluation tools/guidelines used in international development. The proposed WUM model is flexible, considers different levels of institutional capacity, and focuses on processes and practices rather than individual competences. It defines five levels of maturity (initial, basic, proactive, flexible and progressive) against five dimensions of organisational behaviour, structures and processes, technical capabilities, tools and influence. These dimensions may further decomposed into several attributes, which are labelled with distinct and well specified characteristics, depicting a logical progression.

The proposed WUM model was piloted in February 2012 with two large water utilities in South Asia and a focus group discussion with senior managers of one of the utilities confirmed face and content validity of the model. However, more empirical work is required to improve the model structure and confirm its reliability and construct validity. There is also need to develop diagnostic tools for evaluating attributes for each maturity level, create analytic tools, identify barriers to progressing to the next maturity level, and develop institutional development strategies/plans for moving between the maturity levels.

When fully developed and empirically tested, the WUM model will be a valuable tool for water utility managers, who, for lack of institutional capacity self-assessment tools specifically developed for water utility management, have had to adopt generic quality management tools such as ISO 9000 series of standards, most of which are manufacturing-centric. The WUM model could also be used by international donor agencies, and has various potential applications, such as a tool for identifying capacity development activities, stimulating reflection on the management philosophy and focus, organisational learning, benchmarking, and using it as a common language for a shared vision. Although this model has been developed specifically for evaluating institutional capacity of water utilities, the same approach may be used, and indeed some of its aspects can easily be adapted, for use in other utility sectors such as energy and telecommunications.

The conceptual framework on which the WUM model is based recognises that institutional capacity and performance are two distinct development outcomes that are related, though not causally linked. Hence, a public utility may have capacity in a latent form, with poor performance, due to exogenous factors emanating from the operating environment. A major implication of this realisation for policy makers is to balance the focus between capacity and performance, keep the evaluation of capacity and performance of public utilities distinct, and provide an enabling environment for the satisfactory performance of public utilities.

\section{Acknowledgments}

This study was conducted under the auspices of the Sustainable Development Department of the World Bank, and was partly financed by Water Partnership Program and the AusAid Policy and Decentralization Trust Fund. We are grateful to the two anonymous water utilities in Africa who participated in an earlier study that precipitated into the development of the WUM model, and to Vincent Ddamulira and Chimere Diop who carried out the studies. We also thank the two anonymous water utilities in South Asia for participating in the pilot application of the WUM model, and Charles Odonga and Gesner Oliveira for conducting the pilot studies. We are also grateful to the various staff at the World Bank who made very useful comments on the first draft of this paper. 


\section{References}

African Ministers' Council on Water (AMCOW) et al, 2006. Getting Africa on track to meet the MDGs on water \& sanitation: A status overview of sixteen African countries (CSO1).

African Ministers' Council on Water (AMCOW) et al, 2011. AMCOW Country Status Overviews: Pathways to Progress (CSO2).

Aoki, M., 2000. 'Institutional evolution as punctuated equilibria', in C. Menard (ed) Institutions, Contracts and Organizations: Perspectives from New International Economics, Cheltenham: Edward Elgar.

Baietti, A., Kingdom, W. \& van Ginneken, M., 2006. Characteristics of well performing public water utilities, Water and sanitation Working Note No. 9, The World Bank, Washington DC.

Baser, H., Morgan, P., Morgan, J., Brinkerhoff, D., Land, A., Taschereau, S. Watson, D. and Zinke, J., 2008. Capacity, Change and Performance, Discussion Paper No. 59B, European Centre for Development Policy Management.

Bell, S. and Morse, S., 2003. Measuring sustainability: learning by doing. Sterling, VA, Earthscan Publications, London.

Brinkerhoff, D.W. and Goldsmith, A.A., 1992. Promoting the sustainability of development institutions: a framework for strategy, World Development, 20(3), 369-383.

Brinkerhoff, D.W. and Goldsmith, A.A. (eds), 1990. Institutional Sustainability in Agriculture and Rural Development: A Global Perspective, New York: Praeger.

Brinkerhoff, D.W. and Morgan, P.J., 2010. Capacity and capacity development: coping with complexity. Public Administration and Development, 30, 2-10.

Brown, D.R. (1998). Evaluating Institutional Sustainability in Development Programs - Beyond Dollars and Cents. Journal of International Development, 10(1), 55-69.

Brown, L., LaFond, A. and Macintyre, K., 2001. Measuring capacity building, MEASURE Evaluation, University of North Carolina at Chapel Hill, Chapel Hill.

Brunckhorst, D. J., 1998. Guest editorial: Creating institutions to ensure sustainable use of resources. Habitat International, 22(4), 347-354.

Cooke-Davies, T.J., 2005. Measuring Organisational Maturity. Proceedings of the Project Management Institute UK Chapter, London.

Cullivan, D., Tippett, B., Edwards, D.B., Rosensweig, F. and McCaffery, J., 1988. Guidelines for Institutional Assessments Water and Sanitation Institutions, WASH Technical Report No. 37. USAID, Washington DC.

Department for International Development (DFID), UK, 2003. Promoting institutional and organisational development: a sourcebook of tools and techniques, London.

Edwards, A. R. (2005). The Sustainability Revolution: Portrait of a paradigm shift. New Society Publishers, Gabriola Island.

European Commission (2009) Toolkits for capacity development, Reference Document No. 6, EuroAid Tools and Methods Series. Luxembourg.

European Communities (2005) Institutional Assessment and Capacity Development: Why, what and how? Europe Aid Reference Document No. 1. Luxembourg.

Gandhi, V., Crase, L. and Roy, A., 2009. Institutional Analysis of the Performance of Water Institutions in Three Major States of India, in Crase, L. and Gandhi, V.P. (eds) Reforming Institutions in Water Resource Management: Policy and Performance for Sustainable Development, Earthscan, London.

Hill, K., 2008. Understanding institutional sustainability for biodiversity conservation, Paper presented at the annual meeting of the American Sociological Association Annual Meeting, Sheraton Boston and the Boston Marriott Copley Place, Boston, MA, Jul 31, 2008.

Honadle, G.H. and Van Sant, J., 1985. Implementation for Sustainability: Lessons from Integrated Rural Development, Kumarian Press, West Hartford CT. 
Israel, A., 1987. Institutional Development: Incentives to Performance, John Hopkins University Press, Baltimore.

Kaplan, A., 1999. The Developing of Capacity, CDRA, Cape Town, South Africa.

Kimata, Y., 2008. Capacity Assessment for Enhancing Development Effectiveness: Application to JICA Program Management, Institute for International Corporation, Japan International Cooperation Agency, Tokyo, Japan.

Land, T., Hauck, V. and Baser, H., 2009. Capacity Development: between planned interventions and emergent processes - Implications for development cooperation, Policy Management Brief No. 22, ECDPM, Brussels.

Litten, L., 2005. Measuring and reporting institutional sustainability, Annual Forum of the Association for Institutional Research, San Diego, California.

Locussol, A. \& van Ginneken, M., 2008. Template for assessing the governance of public water supply and sanitation service providers, Water Working Note No. 23, The World Bank.

Ludwig, D., B. Walker, and Holling, C.S., 1997. Sustainability, stability and resilience,

Conservation Ecology 1(1), available at http://www.ecologyandsociety.org/vol1/iss1/art7/ (accessed on 6 December 2011).

Lusthaus, C. Anderson, G. Murphy, E., 1995. Institutional Assessment: A framework for strengthening organisational capacity for IDRC's partners, International Development Research Centre, Ottawa, Canada.

Maier, A.M., Moultrie, J. and Clarkson, P.J., 2009. Developing maturity grids for assessing organisational capabilities: Practitioner guidance, University of Cambridge, Cambridge.

Muhairwe, W. T., 2009. Making Public Enterprises Work: From Despair to Promise: a Turn Around Account. IWA Publishing, London.

North, D.C., 1990. Institutions, Institutional change and economic performance, Cambridge University Press, New York.

Norwegian Agency for Development (NORAD), 2000. Handbook in Assessment of Institutional Sustainability. NORAD, Oslo.

Pfahl, S., 2005. Institutional Sustainability. International Journal of Sustainable Development, 8(1/2), 8096.

Saleth, M. and Dinah, A., 2004. The Institutional Economics of Water: A Cross-Country Analysis of Institutions and Performance, The International Bank for Reconstruction and Development/The World Bank, Edward Elgar Publishing Limited, Cheltenham.

Skinner, J., 2009. Where every counts: tackling rural Africa's water crisis, Policy Briefing, The International Institute for Environment and Development (IIED), UK.

Spangenberg, J.H., Pfahl, S. and Deller , K., 2002. Towards indicators for institutional sustainability: lessons from an analysis of Agenda 21, Ecological Indicators, 2, 61-77.

Suez Environment, 2010. The Water International Knowledge Transfer Initiative (WIKTI) - Our vision in sharing our experiences, France, available at http://www.suez-environnement.fr/wpcontent/uploads/2012/01/Brochure-WIKTI_ENG_BAT.pdf?9d7bd4 (accessed on $5^{\text {th }}$ December 2011).

UNDP, 2007. Capacity Development, Technical Advisory Paper No. 2, Management Development and Governance Division, New York.

UNDP, 2008. Capacity Development, Practice Note, New York.

Uphoff, N., 1986. Local Institutional Development: An Analytical Sourcebook with Cases, Kumarian Press, West Hartford.

Wigboldus, S., Nell, A., Brouwer, H. and van der Lee, J., 2010. Making sense of capacity development, Discussion paper for the seminar on International Capacity Building - Recipes for Success, 28 January 2010, Wageningen UR Centre for Development Innovation, The Hague.

World Commission on Environment and Development (WCED) (1987) Our Common Future, Oxford University Press, Oxford. 
Annex 1: Aggregated characteristics of the proposed WUM model

\begin{tabular}{|c|c|c|c|c|c|}
\hline \multirow[b]{2}{*}{ Attributes } & \multicolumn{5}{|c|}{ Maturity level } \\
\hline & $\begin{array}{c}\text { Level } 1 \\
\text { Initial }\end{array}$ & $\begin{array}{c}\text { Level } 2 \\
\text { Basic }\end{array}$ & $\begin{array}{c}\text { Level } 3 \\
\text { Proactive } \\
(\text { Basic }+. . .)\end{array}$ & $\begin{array}{c}\text { Level } 4 \\
\text { Flexible } \\
(\text { Proactive }+\ldots \text { ) }\end{array}$ & $\begin{array}{c}\text { Level 5 } \\
\text { Progressive } \\
\text { (Flexible+...) }\end{array}$ \\
\hline Behaviour & $\begin{array}{l}\text { - Utility is } \\
\text { reactive } \\
\text { - Leadership } \\
\text { roles not well } \\
\text { defined } \\
\text { - No commercial } \\
\text { orientation } \\
\text { - No customer } \\
\text { orientation } \\
\text { - No learning } \\
\text { culture }\end{array}$ & $\begin{array}{l}\text { - Some strategic } \\
\text { orientation (short- } \\
\text { term) } \\
\text { - Competent } \\
\text { managers } \\
\text { - Focus on service } \\
\text { delivery, owners } \\
\text { and some } \\
\text { customers } \\
\text { - Commercial } \\
\text { policies and } \\
\text { strategy exist but } \\
\text { not fully } \\
\text { implemented } \\
\text { - Learning and } \\
\text { improvement } \\
\text { activities are ad } \\
\text { hoc } \\
\end{array}$ & $\begin{array}{l}\text { - Structured process for } \\
\text { formulation of long } \\
\text { term strategy and } \\
\text { policy } \\
\text { - Clear vision, mission } \\
\text { and strategy } \\
\text { - Customer orientation } \\
\text { - Commercial } \\
\text { orientation } \\
\text { - Basic improvement } \\
\text { processes based on } \\
\text { corrective and } \\
\text { preventive actions }\end{array}$ & $\begin{array}{l}\text { - Strategic process } \\
\text { includes needs and } \\
\text { expectations of } \\
\text { broader stakeholders } \\
\text { - Flexible and } \\
\text { performance - } \\
\text { oriented utility } \\
\text { - Improvement is } \\
\text { triggered by customer } \\
\text { satisfaction data and } \\
\text { KPIs } \\
\text { - Improvement efforts } \\
\text { integrated in key } \\
\text { processes and aligned } \\
\text { with strategy, culture } \\
\text { and structure }\end{array}$ & $\begin{array}{l}\text { - Balanced focus on } \\
\text { emerging challenges } \\
\text { - Openness to change, } \\
\text { adaptive } \\
\text { - Learning and innovation } \\
\text { culture } \\
\text { - Continual improvement } \\
\text { based on culture of } \\
\text { learning and sharing }\end{array}$ \\
\hline $\begin{array}{l}\text { Structure/ } \\
\text { Processes }\end{array}$ & $\begin{array}{l}\text { - No defined } \\
\text { structure } \\
\text { - Centralized } \\
\text { authority } \\
\text { - No internal } \\
\text { accountability } \\
\text { mechanisms } \\
\text { - Ad } \\
\text { hoc/disjointed } \\
\text { activities and } \\
\text { processes } \\
\text { - Few stable } \\
\text { processes exit } \\
\text { or are used }\end{array}$ & $\begin{array}{l}\text { - Organizational } \\
\text { structure is } \\
\text { defined } \\
\text { - Some internal } \\
\text { accountability } \\
\text { and autonomy } \\
\text { - Basic processes } \\
\text { and procedures in } \\
\text { place }\end{array}$ & $\begin{array}{l}\text { - Structure is updated } \\
\text { regularly to match } \\
\text { changing needs. } \\
\text { - Performance } \\
\text { management system } \\
\text { and accountability } \\
\text { processes in place } \\
\text { - Different levels of } \\
\text { management are } \\
\text { delegated } \\
\text { - Key utility processes } \\
\text { are defined and } \\
\text { managed }\end{array}$ & $\begin{array}{l}\text { - Organic structure, } \\
\text { supports effective and } \\
\text { efficient processes } \\
\text { - Performance } \\
\text { management systems } \\
\text { with in-built } \\
\text { incentives for } \\
\text { individual and group } \\
\text { performance } \\
\text { - Process planning is } \\
\text { integrated with } \\
\text { strategy development } \\
\text { - Leadership empowers } \\
\text { staff to act with } \\
\text { responsibility and } \\
\text { accountability }\end{array}$ & $\begin{array}{l}\text { - Structure enhances } \\
\text { positive engagement } \\
\text { with customers and } \\
\text { other stakeholders } \\
\text { environment } \\
\text { - Performance } \\
\text { management also } \\
\text { considers a process } \\
\text { approach. } \\
\text { - Structure and systems } \\
\text { support continuous } \\
\text { learning and innovation } \\
\text { - High level of delegation } \\
\text { and autonomy provided } \\
\text { to empowered staff } \\
\text { - Processes are } \\
\text { continuously and } \\
\text { systematically improved }\end{array}$ \\
\hline Capabilities & $\begin{array}{l}\text { - Low capability } \\
\text { of staff } \\
\text { - Roles } \\
\text { unmatched } \\
\text { with technical } \\
\text { competences } \\
\text { - Success } \\
\text { depends on } \\
\text { individual } \\
\text { heroics. } \\
\text { - "Fire-fighting } \\
\text { is a way of } \\
\text { life.” } \\
\text { - Relationships } \\
\text { between } \\
\text { disciplines are } \\
\text { uncoordinated, } \\
\text { perhaps even } \\
\text { adversarial. } \\
\text { - Ad hoc, chaotic } \\
\text { management of } \\
\text { infrastructure } \\
\text { - Chaotic, short- } \\
\text { term financial } \\
\text { management } \\
\text { - Performance } \\
\text { dimensions not } \\
\text { well defined } \\
\text { - Anecdotal } \\
\text { (random) } \\
\text { evidence of } \\
\text { results }\end{array}$ & $\begin{array}{l}\text { - People resources } \\
\text { defined and } \\
\text { assigned in ad } \\
\text { hoc way } \\
\text { - Success depends } \\
\text { on individuals } \\
\text { - Basic SOPs exist } \\
\text { - Breakdown/reacti } \\
\text { ve maintenance } \\
\text { practiced } \\
\text { - Financial } \\
\text { resources defined } \\
\text { and assigned in } \\
\text { an ad hoc way } \\
\text { - Some predictable } \\
\text { performance } \\
\text { results }\end{array}$ & $\begin{array}{l}\text { - HRM processes } \\
\text { defined, measured and } \\
\text { reviewed } \\
\text { - Required technical } \\
\text { competences } \\
\text { identified, actively } \\
\text { sought for and } \\
\text { attracted to stay } \\
\text { - Training is planned } \\
\text { and provided } \\
\text { according to roles. } \\
\text { - Commitments are } \\
\text { understood and } \\
\text { managed. } \\
\text { - People are trained } \\
\text { - SOPs for all utility } \\
\text { processes } \\
\text { implemented } \\
\text { - Preventive } \\
\text { maintenance } \\
\text { management systems } \\
\text { in place } \\
\text { - Quality management } \\
\text { systems implemented } \\
\text { - Resource allocation } \\
\text { for critical } \\
\text { infrastructure } \\
\text { development } \\
\text { - Processes exist for } \\
\text { predicting, monitoring } \\
\text { and controlling } \\
\text { financial resources } \\
\text { - Performance results }\end{array}$ & $\begin{array}{l}\text { - HR processes are } \\
\text { integrated fully with } \\
\text { day-to-day operations } \\
\text { - Periodic review of the } \\
\text { efficiency and } \\
\text { effectiveness of the } \\
\text { work environment } \\
\text { - A strong sense of } \\
\text { teamwork exists } \\
\text { - Staff encouraged and } \\
\text { provided with } \\
\text { resources to } \\
\text { continuously develop } \\
\text { competences } \\
\text { - Holistic asset } \\
\text { management and } \\
\text { planning is } \\
\text { implemented } \\
\text { - Agility, flexibility and } \\
\text { innovation is } \\
\text { supported by the } \\
\text { management system } \\
\text { - Consistent, positive } \\
\text { performance results, } \\
\text { sustained trends }\end{array}$ & $\begin{array}{l}\text { - A strong sense of } \\
\text { teamwork exists across } \\
\text { the utility } \\
\text { - Evidence of improving } \\
\text { trends of staff } \\
\text { motivation and } \\
\text { involvement } \\
\text { - Everyone is involved in } \\
\text { process improvement. } \\
\text { - Leadership motivates } \\
\text { and supports staff to } \\
\text { create innovations in } \\
\text { technical processes } \\
\text { - Recognition systems are } \\
\text { in place for teams and } \\
\text { individuals generating } \\
\text { strategically relevant } \\
\text { improvements; } \\
\text { - Learning is considered } \\
\text { important and supported } \\
\text { by top management, } \\
\text { who lead by example } \\
\text { - Risk assessment and } \\
\text { management being } \\
\text { implemented } \\
\text { - Financial resource risks } \\
\text { are identified, future } \\
\text { financial needs are } \\
\text { forecast and planned } \\
\text { - Performance results are } \\
\text { above sector average } \\
\text { achieved and } \\
\text { maintained in the long- }\end{array}$ \\
\hline
\end{tabular}




\begin{tabular}{|c|c|c|c|c|c|}
\hline & & & are predictable & & term \\
\hline Tools & $\begin{array}{l}\text { - Limited use of } \\
\text { technology and } \\
\text { systems } \\
\text { - Introduction of } \\
\text { new technology } \\
\text { is considered } \\
\text { risky } \\
\text { - Operational } \\
\text { data collection } \\
\text { and analysis } \\
\text { are ad hoc. } \\
\text { - Evaluation of } \\
\text { performance } \\
\text { rarely } \\
\text { conducted; } \\
\text { principally } \\
\text { externally } \\
\text { driven } \\
\text { - Knowledge } \\
\text { sharing is not } \\
\text { actively } \\
\text { encouraged, } \\
\text { and no tools in } \\
\text { place } \\
\text { There is no } \\
\text { policy or tools } \\
\text { for information } \\
\text { dissemination }\end{array}$ & $\begin{array}{l}\text { - Basic technology } \\
\text { and systems in } \\
\text { place, and in use } \\
\text { - Monitoring is } \\
\text { performed on a } \\
\text { sporadic basis, } \\
\text { with no processes } \\
\text { in place. } \\
\text { - There is a policy } \\
\text { to encourage } \\
\text { knowledge } \\
\text { sharing, but is not } \\
\text { fully } \\
\text { implemented; } \\
\text { sharing still ad } \\
\text { hoc } \\
\text { - There is a policy } \\
\text { in place, but not } \\
\text { implemented; } \\
\text { communication } \\
\text { takes place in a } \\
\text { reactive way }\end{array}$ & $\begin{array}{l}\text { - Integrated IT systems } \\
\text { and operational } \\
\text { systems and tools are } \\
\text { in place } \\
\text { - Operational data is } \\
\text { collected and used in } \\
\text { all defined processes. } \\
\text { - Operational data is } \\
\text { systematically shared } \\
\text { across the utility } \\
\text { - A periodic monitoring } \\
\text { process in place, } \\
\text { focused on customer } \\
\text { needs and } \\
\text { expectations; } \\
\text { - Systematic data } \\
\text { analysis used to } \\
\text { identify needs and } \\
\text { expectations of } \\
\text { interested parties. } \\
\text { - A process to identify, } \\
\text { obtain, protect, use } \\
\text { and evaluate } \\
\text { information and } \\
\text { knowledge is } \\
\text { implemented. } \\
\text { - A process for external } \\
\text { and internal } \\
\text { communication is } \\
\text { defined; IT systems } \\
\text { are protected. } \\
\end{array}$ & $\begin{array}{l}\text { - Data definition and } \\
\text { collection are } \\
\text { standardized across } \\
\text { the utility } \\
\text { - Data is used to } \\
\text { understand the utility } \\
\text { processes } \\
\text { qualitatively and } \\
\text { stabilize/improve } \\
\text { them } \\
\text { - The monitoring } \\
\text { process is regularly } \\
\text { evaluated } \\
\text { - Information and } \\
\text { knowledge are shared } \\
\text { within the utility and } \\
\text { periodic reviews take } \\
\text { place; } \\
\text { - Effective system and } \\
\text { tools are in place to } \\
\text { communicate the } \\
\text { changes in strategy } \\
\text { and plans to relevant } \\
\text { staff. }\end{array}$ & $\begin{array}{l}\text { - New technologies are } \\
\text { proactively pursued and } \\
\text { deployed } \\
\text { - } \text { Data is used to evaluate } \\
\text { and select process } \\
\text { improvements } \\
\text { - The monitoring process } \\
\text { is performed in a } \\
\text { systematic and planned } \\
\text { manner, and includes } \\
\text { cross-checks with } \\
\text { external data sources; } \\
\text { - Improvements in } \\
\text { management system are } \\
\text { propelled by systematic } \\
\text { benchmarking } \\
\text { - Information and } \\
\text { knowledge are shared } \\
\text { with partners and other } \\
\text { interested parties; } \\
\text { - Information and } \\
\text { knowledge is processed } \\
\text { to meet future needs; } \\
\text { - Changes in policy are } \\
\text { communicated to } \\
\text { relevant interested } \\
\text { parties, and to all levels } \\
\text { of the organization. } \\
\text { The effectiveness of the } \\
\text { communication process } \\
\text { is reviewed periodically. }\end{array}$ \\
\hline Influence & $\begin{array}{l}\text { - Leadership and } \\
\text { staff not well } \\
\text { conversant with } \\
\text { factors in the } \\
\text { external } \\
\text { environment. } \\
\text { - Partnerships } \\
\text { and networks } \\
\text { with outside } \\
\text { organizations } \\
\text { are not } \\
\text { supported } \\
\text { - Corporate } \\
\text { image is not } \\
\text { recognized as } \\
\text { an important } \\
\text { service element } \\
\text { and is not } \\
\text { evaluated } \\
\text { - Utility } \\
\text { managers lack } \\
\text { autonomy to } \\
\text { make important } \\
\text { managerial and } \\
\text { operational } \\
\text { decisions } \\
\text { - Negative } \\
\text { political } \\
\text { influence is } \\
\text { common } \\
\text { There is no } \\
\text { external } \\
\text { accountability } \\
\text { for } \\
\text { performance }\end{array}$ & $\begin{array}{l}\text { - Leadership } \\
\text { passively } \\
\text { interested in } \\
\text { factors in the } \\
\text { external } \\
\text { environment, and } \\
\text { reacts to them } \\
\text { rather than } \\
\text { strategically } \\
\text { influencing them. } \\
\text { - Partnerships and } \\
\text { networks may be } \\
\text { initiated by } \\
\text { individual staff; } \\
\text { - Supplier } \\
\text { communications } \\
\text { are limited to } \\
\text { tendering, order } \\
\text { placement or } \\
\text { problem } \\
\text { resolution } \\
\text { - Leadership is } \\
\text { aware of the } \\
\text { importance of } \\
\text { corporate image; } \\
\text { however, it is not } \\
\text { monitored or } \\
\text { evaluated in a } \\
\text { consistent and } \\
\text { systematic } \\
\text { manner } \\
\text { There is limited } \\
\text { managerial and } \\
\text { operational } \\
\text { autonomy } \\
\text { External } \\
\text { accountability } \\
\text { mechanisms in } \\
\text { place but not } \\
\text { effective }\end{array}$ & $\begin{array}{l}\text { - The external } \\
\text { environment is } \\
\text { actively monitored to } \\
\text { develop } \\
\text { understanding and } \\
\text { reduce uncertainty } \\
\text { - There is a policy that } \\
\text { encourages and } \\
\text { supports mutually } \\
\text { beneficial } \\
\text { partnerships and } \\
\text { networking; } \\
\text { - Processes are in place } \\
\text { to select, evaluate and } \\
\text { rank suppliers } \\
\text { - Corporate image is } \\
\text { periodically measured } \\
\text {; but the results are } \\
\text { not necessarily used } \\
\text { for improvements } \\
\text { - Managers have more } \\
\text { room to maneuver and } \\
\text { innovate (i.e. have } \\
\text { autonomy to effect } \\
\text { internal } \\
\text { managerial/operationa } \\
\text { l changes to improve } \\
\text { the effectiveness and } \\
\text { productivity } \\
\text { The utility is held } \\
\text { accountable for } \\
\text { performance by some } \\
\text { of the external } \\
\text { stakeholders }\end{array}$ & $\begin{array}{l}\text { - Leadership } \\
\text { continuously scanning } \\
\text { the external } \\
\text { environment, and } \\
\text { adapting to changes } \\
\text { through building } \\
\text { organizational } \\
\text { capacity for effective } \\
\text { negotiation, and } \\
\text { alignment of business } \\
\text { processes, building } \\
\text { networks and allies } \\
\text { - There is a budge to } \\
\text { develop and grow } \\
\text { partnerships and } \\
\text { networks; } \\
\text { - Relationship } \\
\text { processes exist to } \\
\text { develop key suppliers } \\
\text { - Corporate image is } \\
\text { continuously and } \\
\text { systematically } \\
\text { tracked. The results } \\
\text { are widely made } \\
\text { available inside the } \\
\text { organization and used } \\
\text { in the strategic } \\
\text { planning process } \\
\text { - Utility has full } \\
\text { autonomy with } \\
\text { respect to most } \\
\text { managerial, } \\
\text { operational and } \\
\text { financial decisions } \\
\text { - Utility is held } \\
\text { accountable for } \\
\text { performance by some } \\
\text { external stakeholders }\end{array}$ & $\begin{array}{l}\text { - Utility has predictive } \\
\text { capabilities, and carries } \\
\text { out risk/opportunities } \\
\text { assessment and } \\
\text { management; } \\
\text { continuously adaptive to } \\
\text { the external } \\
\text { environment in near } \\
\text { real-time; } \\
\text { - Partnerships are } \\
\text { integrated within } \\
\text { business processes } \\
\text { - The results of the } \\
\text { corporate image scans } \\
\text { are integrated into the } \\
\text { performance/incentive } \\
\text { management system for } \\
\text { staff } \\
\text { - Utility has full } \\
\text { autonomy with respect } \\
\text { to all managerial, } \\
\text { operational and } \\
\text { financial decisions } \\
\text { - Utility has a balanced } \\
\text { accountability } \\
\text { framework }\end{array}$ \\
\hline
\end{tabular}




\section{List of Figures}

Figure 1: Elements of capacity (source: Baser et al, 2008)

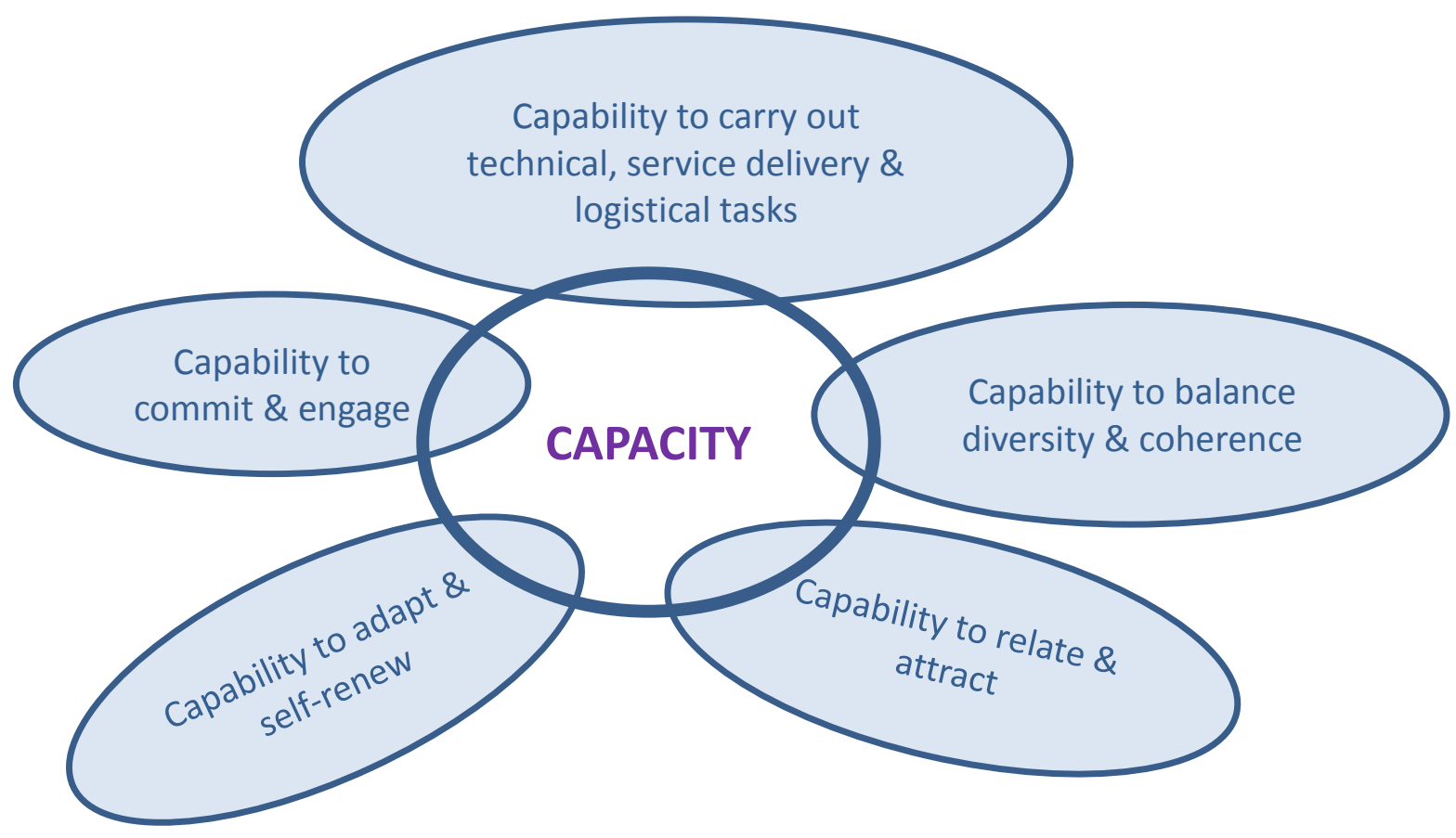

Figure 2: Dimensions and attributes of the WUM Model

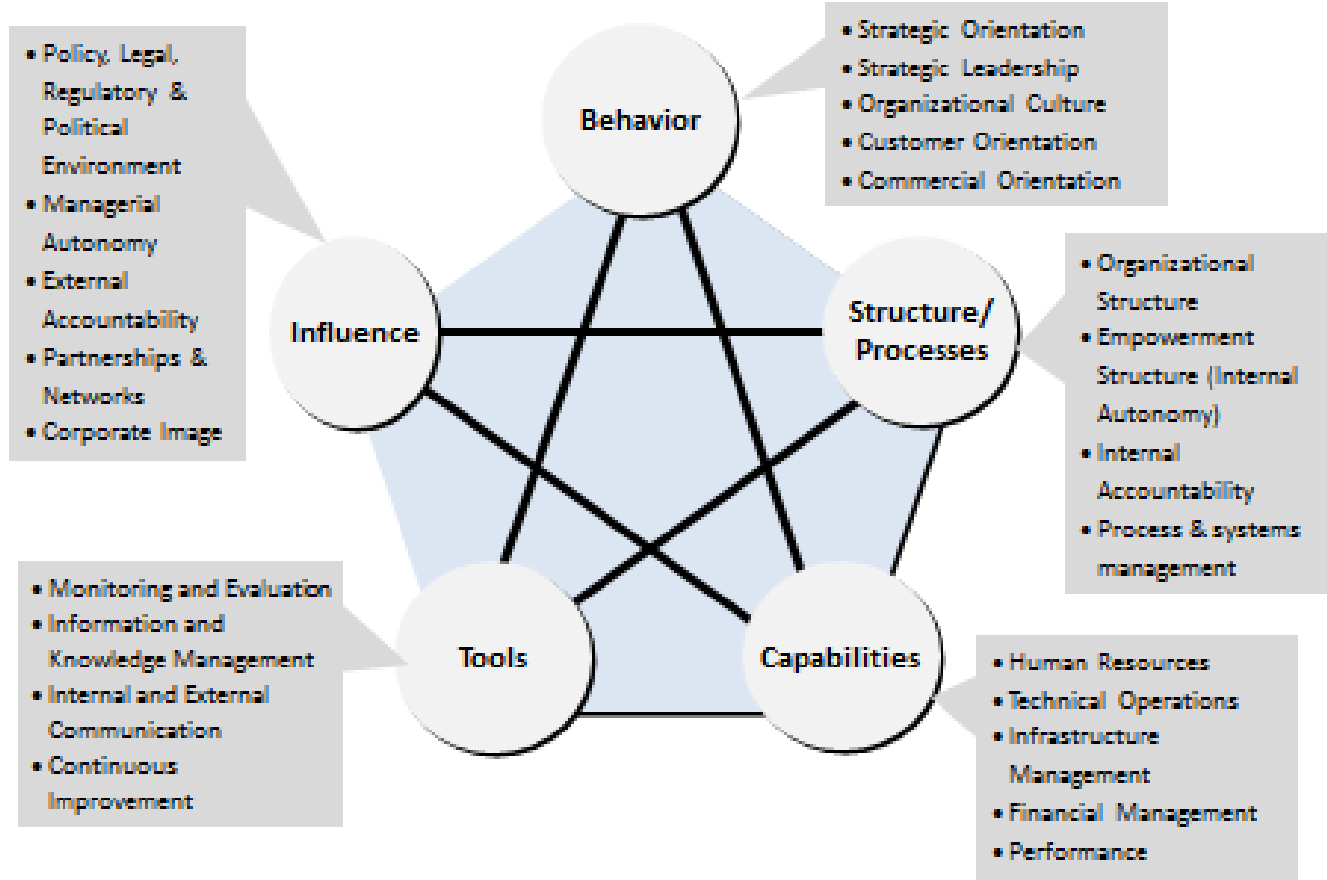


Figure 3: Labelled progressive maturity levels for the attribute of ‘strategic orientation'.

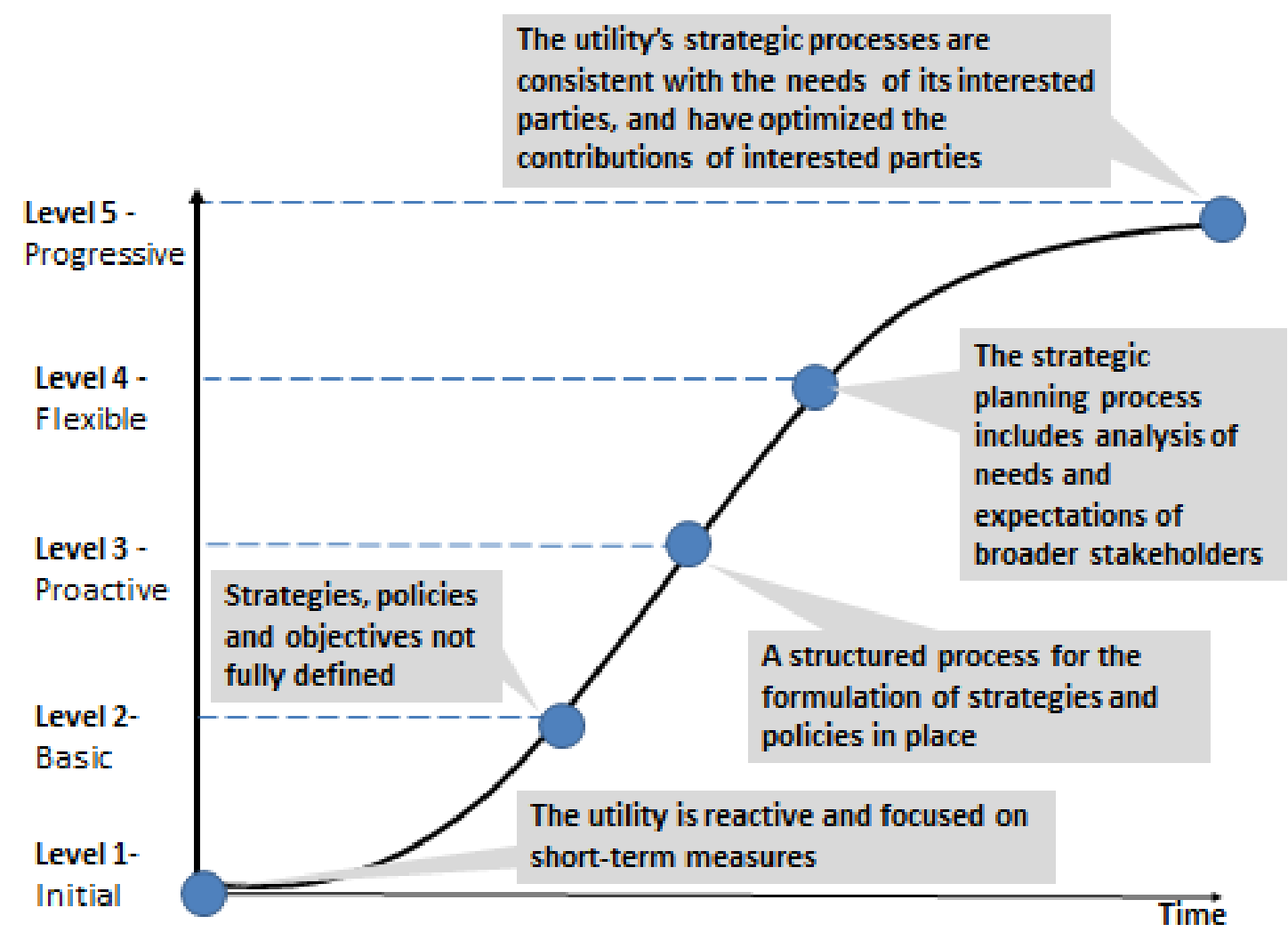

Figure 4: Results of a pilot application of WUM Model by two urban water utilities in South Asia.

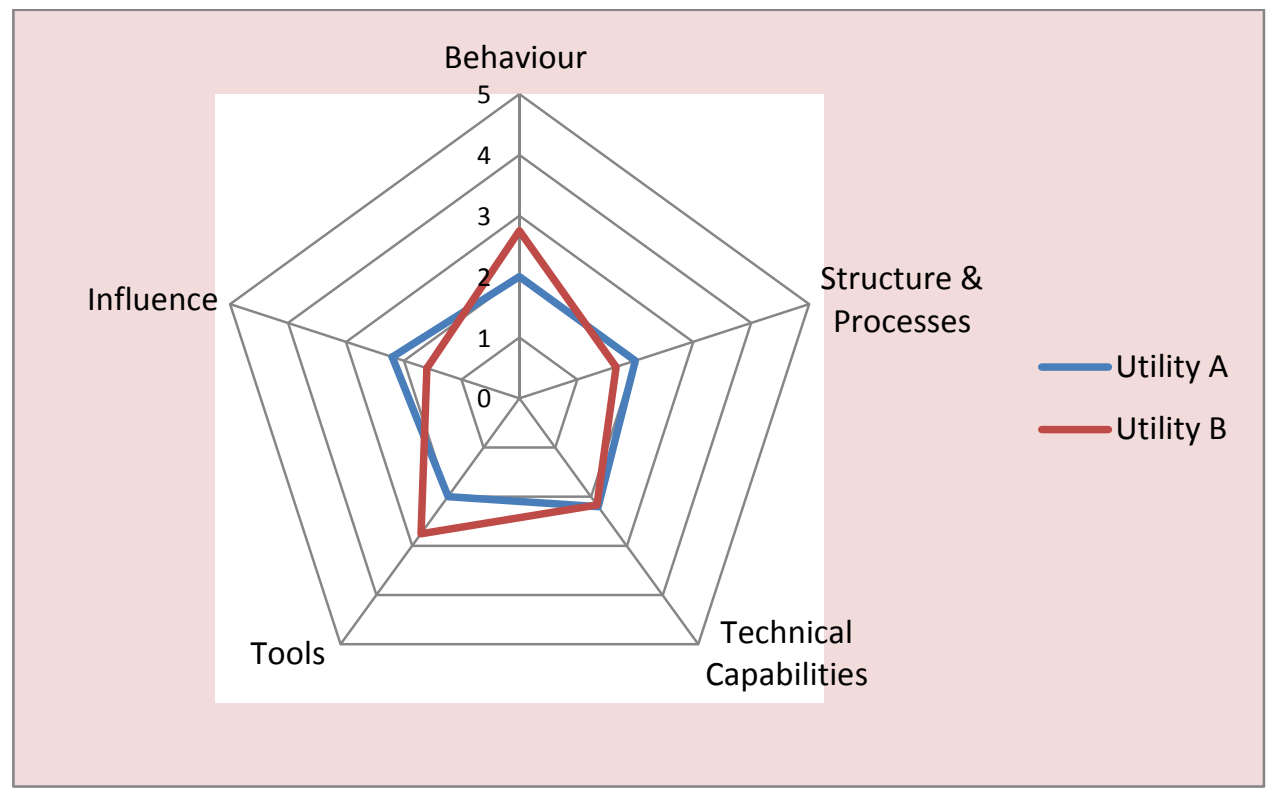

